\title{
Animal performance, production, and quality of Tanzania grass fertilized with nitrogen
}

\section{Desempenho animal, produção e valor nutritivo do capim Tanzânia adubado com nitrogênio}

\author{
Ulysses Cecato ${ }^{1}$; Josmar Almeida Junior ${ }^{2}$; Fabiola Cristine de Almeida Rego ${ }^{3 *}$; \\ Sandra Galbeiro ${ }^{4}$; Wagner Paris ${ }^{5}$; Carlos Alberto Scapim ${ }^{6}$; Augusto Manoel \\ Rodrigues ${ }^{7}$; Glauber Marcelo Fakir ${ }^{8}$
}

\begin{abstract}
This study aimed to assess forage production, animal performance, and the chemical composition of Tanzania grass pasture fertilized with $50,100,200$, and $400 \mathrm{~kg} \mathrm{ha}^{-1}$ of nitrogen. The variables analyzed were: leaf mass, daily accumulation rate, leaf/stem ratio, average daily gain, stocking rate, live weight gain per unit of area crude protein, neutral detergent fiber, and in vitro dry matter digestibility of leaves. The pasture management maintained the pasture height at $50 \mathrm{~cm}$ by using a continuous grazing method with the adjustment of stocking rate. The experimental design was a randomized block with three replicates. The leaf mass increased linearly in response to nitrogen, with an increase of $1003 \mathrm{~kg}(34 \%)$ observed between a nitrogen content of 50 and $400 \mathrm{~kg} \mathrm{ha}^{-1}$. Nitrogen did not affect the average daily gain, but increased the stocking rate and live weight gain $\mathrm{ha}^{-1}$. The value of crude protein and neutral detergent fiber were higher with increased nitrogen levels, whereas the leaf digestibility did not affect nitrogen use. The comparison of 50 and $400 \mathrm{~kg} \mathrm{ha}^{-1}$ levels indicated that there was an average increase of $19.2 \%$ in the leaf crude protein. The increased application of nitrogen fertilizer in Tanzania grass improved the chemical composition and animal performance; with regard to studied variables, the dose of $200 \mathrm{~kg} \mathrm{ha}^{-1}$ resulted in the greatest improvement.
\end{abstract}

Key words: Beef cattle. Dry matter digestibility. Weight gain. Beef cattle. Stocking rate. Crude protein content.

\section{Resumo}

Esta pesquisa teve como objetivo avaliar a produção de forragem, o desempenho animal e a composição química da pastagem de capim Tanzânia adubada com 50; 100; 200 e $400 \mathrm{~kg} \mathrm{ha}^{-1}$ de nitrogênio (N). As

1 Prof., Dr., Universidade Estadual de Maringá, UEM, Departamento de Zootecnia, Programa de Pós-Graduação em Zootecnia, Maringá, PR, Brasil. Pesquisador do CNPq. E-mail: ucecato@uem.br

2 M.e, em Zootecnia, Assessoria e Consultoria TECNOPASTO, Goioerê, PR, Brasil, E-mail: tecnopasto@hotmail.com

3 Prof ${ }^{a}$ Dra $^{a}$, Universidade Norte do Paraná, UNOPAR, Prof ${ }^{a}$ Titular do Programa de Pós-Graduação em Saúde e Produção de Ruminantes, Arapongas, PR, Brasil. E-mail: fabiolaregogrecco@gmail.com

4 Prof $^{a}$ Dr $^{\mathrm{a}}$, Universidade Estadual de Londrina, UEL, Departamento de Zootecnia, Londrina, PR, Brasil. E-mail: sgalbeiro@uel.br

5 Prof., Dr., Universidade Tecnológica Federal do Paraná, UTFPR, Prof. Permanente do Programa de Pós-Graduação em Zootecnia, Dois Vizinhos. PR, Brasil. E-mail: wagparis@yahoo.com.br

6 Prof., Dr., UEM, Departamento de Agronomia, Programa de Pós-Graduação em Genética e Melhoramento, Maringá, PR, Brasil. Pesquisador do CNPq. E-mail: cascapim@uem.br

7 Prof., Dr., Instituto Federal de Mato Grosso do Sul, IFMS, Nova Andradina, MS, Brasil. E-mail: augusto.rodrigues@ifms.edu.br

8 Zootecnista, Maringá, PR, Brasil. E-mail: glauber.fakir11@gmail.com

* Author for correspondence 
variáveis analisadas foram: massa de lâminas foliares, taxa de acúmulo diário, relação lâmina foliar: colmo, ganho de peso médio diário, taxa de lotação, ganho de peso vivo por área $\left(\mathrm{kg} \mathrm{ha}^{-1}\right)$, teores de proteína bruta, fibra em detergente neutro e digestibilidade in vitro da matéria seca. O manejo adotado foi a manutenção da altura do pasto em $50 \mathrm{~cm}$, pastejo com lotações contínuas e cargas variáveis. $\mathrm{O}$ delineamento experimental utilizado foi de blocos casualizados com três repetições. A massa seca de lâminas foliares aumentou linearmente em resposta as doses de $\mathrm{N}$, incrementando $1.003 \mathrm{~kg}$ da dose 50 em relação a dose de $400 \mathrm{~kg} \mathrm{ha}^{-1}$, o que representa aumento de $34 \%$. O adubo nitrogenado não influenciou o ganho médio diário, porém incrementou linearmente a taxa de lotação e, consequentemente o ganho de peso vivo ha ${ }^{-1}$. Também houve aumento e redução linear da proteína bruta e fibra em detergente neutro das lâminas foliares respectivamente com o incremento das doses de nitrogênio, enquanto a digestibilidade das lâminas foliares não alterou pelo uso do nitrogênio. Quando comparadas as doses de 50 e $400 \mathrm{~kg} \mathrm{ha}^{-1}$, verificou-se incremento médio de 19,2\% da proteína bruta da lâmina foliar. Os incrementos nas doses de nitrogênio em capim Tanzânia melhoraram a composição química e a produção animal, sendo que a dose de $200 \mathrm{~kg} \mathrm{ha}^{-1}$ foi a mais indicada com relação às variáveis estudadas.

Palavras-chave: Bovinos. Digestibilidade da matéria seca. Ganho de peso. Taxa de lotação. Teor de proteína bruta.

\section{Introduction}

The extractive exploration adopted by producers has led to a general, continuous degradation of Brazilian grasslands, which represents one of the major problems of livestock farming. This situation can be mainly attributed to inadequate management and the lack of replenishment of soil nutrients. A sustainable production system requires fertilization, and nitrogen is the nutrient with the greatest impact. The optimal dose of fertilizer will depend on the species and the edaphic conditions and climatic conditions of the region. For Tanzania grass, the use of $50 \mathrm{~kg} \mathrm{~N} \mathrm{ha-1}$ per year is sufficient to keep the forage yield stable for 3 years; from the fourth year of pasture use, it is necessary to increase the dose to $100 \mathrm{~kg} \mathrm{ha}^{-1}$ per year (EUCLIDES et al., 2008).

Tanzania grass (Panicum maximum) has a high production potential and good nutritional value (CANO et al., 2004; REGO et al., 2004). It should be emphasized that the dry matter accumulation rate and the structural characteristics of the pasture may be altered in accordance with the management adopted, such as varying the height of the pasture (CANTO et al., 2008) or the intensity of grazing (MARTHA JUNIOR et al., 2004).

Additionally, the effects of nitrogen fertilization vary according several factors, including the levels of use, the climate, and the species. Species of the genus Panicum exhibit significant responses to nitrogen fertilization; for example, the production of Mombasa grass was better with a dose of 500 $\mathrm{kg} \mathrm{ha}^{-1} \mathrm{~N}$ (BRAGA et al., 2004). Another study that tested nitrogen fertilization at 50,100, and $200 \mathrm{~kg}$ $\mathrm{ha}^{-1} \mathrm{~N}$ in Tanzania and Mombasa grasses showed improvements in the chemical composition in winter and spring seasons (PARIZ et al., 2011).

In addition to the productive and quality characteristics, nitrogen fertilization is known to alter the morphogenetic characteristics of Tanzania grass. Soares Filho et al. (2015) evaluated increasing levels of $\mathrm{N}$ and observed increases in rates of elongation, leaf appearance, and in the number of live leaves during the spring and summer, which lead to higher percentages of leaf blades in the pasture.

Studies have shown that these improvements in the productivity and quality of fertilized pastures lead to the increased consumption of forage (REGO et al., 2006); furthermore, as pasture is the main source of nutrients, this will almost certainly lead to an increase in animal performance.

The proper management of pastures coupled with the use of technologies such as fertilization can produce improve the animal and plant performance. Thus, the objective of this study was to evaluate animal production, chemical composition, and 
digestibility of dry matter of Tanzania grass fertilized with different rates of nitrogen.

\section{Material and Methods}

This experiment was conducted in the Northwest region of Paraná, between November 22, 2000, and May 23, 2001. The soil was of arenito Caiuá origin and characterized as yellow red argisol (EMBRAPA, 2013) with a low $\mathrm{pH}$, low cation exchange capacity (CEC), low organic matter content and low phosphorus content. The climate of the region is classified as subtropical humid, mesothermic, with hot summers and infrequent frosts, and with rainfall concentrated in the summer (Cfa). The latitude and longitude were $23^{\circ} 22^{\prime} 12^{\prime \prime} \mathrm{S}$ longitude $52^{\circ} 03^{\prime} 54^{\prime \prime} \mathrm{W}$, respectively, and the altitude was $545 \mathrm{~m}$.

Tanzania grass pasture (Panicum maximum Jacq 'Tanzania') was established from July to August 2000 and divided into 12 experimental units (pickets) between 0.7 and 1.0 ha, which occupied a total area of 10.2 ha. A plot of 2.00 ha, adjacent to the experimental area, with the same forage grass, was used for the maintenance of the pastureregulating animals.

Phosphorus and potassium fertilizer were applied in the forms of superphosphate $\left(80 \mathrm{~kg} \mathrm{ha}^{-1}\right.$ of $\left.\mathrm{P}_{2} \mathrm{O}_{5}\right)$ and potassium chloride $\left(100 \mathrm{~kg} \mathrm{ha}^{-1}\right.$ of $\left.\mathrm{K}_{2} \mathrm{O}\right)$. The first application was distributed at planting and the second was divided as follows: $40 \%$ at planting and $60 \%$ together with nitrogen fertilizer.

Four nitrogen treatment levels were tested: 50, 100,200 , and $400 \mathrm{~kg} \mathrm{ha}^{-1} \mathrm{~N}$, used in compounds containing $80 \%$ urea and $20 \%$ ammonium sulfate. The $50 \mathrm{~kg} \mathrm{~N}$ dose comprised $88.88 \mathrm{~kg}$ urea and $47.67 \mathrm{~kg}$ of ammonium sulfate, the $100 \mathrm{~kg}$ dose comprised $177.77 \mathrm{~kg}$ urea and $95.23 \mathrm{~kg}$ of ammonium sulfate, the $200 \mathrm{~kg}$ dose comprised $355.55 \mathrm{~kg}$ urea and $190.47 \mathrm{~kg}$ ammonium sulfate, and the $400 \mathrm{~kg}$ dose comprised $711.11 \mathrm{~kg}$ urea and $380.95 \mathrm{~kg}$ ammonium sulfate. The dose was divided into four equal applications and distributed over the rainy season (October 2004 to April 2005).

The experiment was arranged in a randomized block design with three replications. The grazing method was continuous stocking with variable load. For the maintenance of the desired $50 \mathrm{~cm}$ height (CANO et al. 2004), non-castrated Nelore and Red Angus crossbred steers, with average weight of $330 \pm 3.82 \mathrm{~kg}$, were used. Three tester animals were used per picket in addition to the regulator animals, which were placed or removed as needed to attain the $50 \mathrm{~cm}$ pasture height predetermined for all treatments, in accordance with the technique of Mott and Lucas (1952).

The animal load was adjusted every 2 weeks, depending to the height of the pasture, which was estimated through the aid of a $2.0 \mathrm{~m}$ graduated ruler, with 50 samples measured every 7 days per experimental unit. The estimation of the height of the canopy considered the end or the point of curvature of the blade of the highest leaf, from the ground level at the point of sampling; samples were randomly selected.

The estimation of the dry forage weight available per area was performed every 28 days by the double sampling method (GARDNER, 1986). Four 0.50 $\mathrm{m}^{2}$ samples per picket were picked at random and assessed visually by previously trained personnel. In addition, ten representative samples of the mean grass height were visually evaluated. The equation proposed by Gardner (1986) was used to calculate the dry mass ha-1.

A sub-sample of the material collected in the double-sampling was used to determine the leaf blade: stem (LS) ratio. This material was separated into leaf blade, stalk (stem plus leaf sheath), and senescent material (leaves and stems), dried in an oven at $55^{\circ} \mathrm{C}$ for $72 \mathrm{~h}$, milled in a knife mill through a $1 \mathrm{~mm}$ sieve, and conditioned for further analysis. The leaf blade: stem ratio was calculated from the quotient of the dry mass of the leaf blades and the stems. 
The animal performance was evaluated by the measurement of animal weight, at the beginning of the experimental period, every 28 days, and at the end of the experimental period. The tester and regulator animals were weighed after fasting for approximately $12 \mathrm{~h}$.

The stocking rate was calculated from the multiplication of the number of animals of each picket by their live weight and the division of this result by the area of the picket and by $450 \mathrm{~kg}$ (1 UA). The average daily weight gain of the animals was estimated from the subtraction of the initial weight of each animal from the final weight and the division of this value by the number of days that each animal remained in the experimental unit. The gain of live weight per unit area was calculated from the product of the number of animals per day per ha and the average daily weight gain of the tester animals (PETERSEN; LUCAS, 1968).

The chemical composition of the leaf blades was performed on the material harvested in the double sampling. The in vitro digestibility dry matter (IVDMD) was conducted in accordance with the methodology of Tilley and Terry (1963), dry matter (DM) and crude protein (CP) were measured according to AOAC (1990), and the neutral detergent fiber (NDF) was measured according to
Van Soest (1991).

The parameters were statistically analyzed by using analysis of variance; when significant differences were identified at the $5 \%$ level, regression analysis for the treatments was computed using the SAS program (1999).

\section{Results and Discussion}

The mass of leaf blades increased linearly ( $\mathrm{P}$ $<0.01$ ) with nitrogen levels (Table 1), increasing by $1003 \mathrm{~kg}(34 \%)$ between the $50 \mathrm{~kg}$ and the 400 $\mathrm{kg}$ dose level. The increased levels of nitrogen led to an increase in the contribution of the leaf mass to the total mass, most likely as a result of greater tillering. This change in the structure of the canopy is important as it directly affects the feeding rate of the animals; the percentage and mass of green leaves in the pasture are two of the most relevant variables (REGO et al., 2006). Ribeiro et al. (2011), observed that the application of $225 \mathrm{~kg} \mathrm{~N} \mathrm{ha}^{-1} \mathrm{y}^{-1}$ on Tanzania grass provided greater leaf mass availability in the seasons with better climatic conditions, which resulted in higher performance and animal production per area compared with intercropping with Campo Grande Stylosanthes.

Table 1. Average values of the dry mass of leaf blade (DMLB, $\mathrm{kg} \mathrm{ha}^{-1}$ ), dry mass stem (DMS, $\mathrm{kg} \mathrm{ha}^{-1}$ ), dry mass of senescent material (DMSM, $\mathrm{kg} \mathrm{ha}^{-1}$ ), total dry mass (TDM, $\mathrm{kg} \mathrm{ha}^{-1}$ ), and leaf: stem ratio (L:S) of Tanzania grass fertilized with different nitrogen rates.

\begin{tabular}{lccccccc}
\hline \multicolumn{5}{c}{ Nitrogen rates $\left(\mathrm{kg} \mathrm{ha}^{-1}\right)$} & & & \\
\cline { 1 - 5 } \multicolumn{1}{c}{ Variables } & 50 & 100 & 200 & 400 & Equation & ${ }^{*} \mathrm{CV}(\%)$ & ${ }^{* *} \mathrm{R}^{2}$ \\
\hline DMLB $\left(\mathrm{kg} \mathrm{ha}^{-1}\right)$ & 2926 & 2882 & 3326 & 3929 & $\mathrm{Y}=2686+3.09 \mathrm{X}$ & 67.4 & 0.96 \\
DMS $\left(\mathrm{kg} \mathrm{ha}^{-1}\right)$ & 4731 & 4261 & 4885 & 4792 & 4667 & 46.9 & - \\
DMSM $\left(\mathrm{kg} \mathrm{ha}^{-1}\right)$ & 6522 & 4853 & 6052 & 4964 & 5597 & 64.57 & - \\
TDM $\left(\mathrm{kg} \mathrm{ha}^{-1}\right)$ & 14178 & 11995 & 14263 & 13685 & 13530 & 42.0 & - \\
L:S & 1.06 & 0.86 & 0.85 & 1.02 & 0.92 & 96.2 & - \\
\hline
\end{tabular}

$* \mathrm{CV}$ : Coefficient of variation; ** $\mathrm{R}^{2}$ : coefficient of determination. 
The masses of stem and senescent material were not significantly different $(\mathrm{P}>0.05)$ between nitrogen levels (Table 1) in the ranges 4261-4885 $\mathrm{kg} \mathrm{ha}{ }^{-1}$ for stem mass and 4853-6522 $\mathrm{kg} \mathrm{ha}^{-1}$ for the mass of senescent material. Given that all the pastures received the same management; that is, the maintenance of the same pasture height at all nitrogen levels, this was thought to contribute to the similarity in the responses of the variables. A study performed by Magalhães et al. (2007), which evaluated Brachiaria decumbens, reported linear increases in the dry mass of stalks with increases in nitrogen levels and quadratic responses for the leaf: stem ratio, which reduced the effect of 200 $\mathrm{kg} \mathrm{N} \mathrm{Na}^{-1}$ fertilizer and led to decreases in animal consumption as a result of the animal's preference for leaves.
Even with the increase in leaf mass and nitrogen levels, the leaf: stem ratio and the total dry mass remained unchanged, with mean values of 0.92 and $13.530 \mathrm{~kg} \mathrm{ha}^{-1}$ (Table 1), respectively. The unchanged nature of the variables showed that even with differences in the applied fertilizer (i.e., increased nitrogen levels), the management used was satisfactory for the maintenance of $50 \mathrm{~cm}$ high pasture and permitted the animals an average daily weight gain of $1 \mathrm{~kg}$ (Table 2), regardless of the fertilization used. The mean value of 13 tons of total dry matter availability did not limit consumption and animal performance. The dry matter intake is directly related to the availability of forage and restrictions on the available forage lead to reductions in intake owing to reduced bite sizes and increased grazing time (MINSON, 1990).

Table 2. Mean values of average daily weight gain (DWG, kg animal ${ }^{-1}$ day $^{-1}$ ), live weight gain per area (LWG, kg $\mathrm{ha}^{-1}$ ), and stocking rate (SR, UA ha ${ }^{-1}$ ) of the animals on Tanzania grass pasture fertilized with different nitrogen rates.

\begin{tabular}{|c|c|c|c|c|c|c|c|}
\hline \multirow[b]{2}{*}{ Variables } & \multicolumn{4}{|c|}{ Nitrogen rates $\left(\mathrm{kg} \mathrm{ha}^{-1}\right)$} & \multirow[b]{2}{*}{ Equation } & \multirow[b]{2}{*}{$* \mathrm{CV}(\%)$} & \multirow[b]{2}{*}{$* * \mathrm{R}^{2}$} \\
\hline & 50 & 100 & 200 & 400 & & & \\
\hline DWG $\left(\mathrm{kg}\right.$ animal ${ }^{-1}$ day $\left.^{-1}\right)$ & 0.99 & 1.15 & 1.03 & 1.1 & 1.06 & 43 & - \\
\hline LWG $\left(\mathrm{kg} \mathrm{ha}^{-1}\right)$ & 653 & 675 & 723 & 813 & $\mathrm{Y}=716.4+1.47 \mathrm{X}$ & 65.3 & 0.8 \\
\hline SR $\left(\mathrm{UA} \mathrm{ha}^{-1}\right)$ & 4.0 & 3.7 & 5.0 & 6.6 & $\mathrm{Y}=3.25+0.0084 \mathrm{X}$ & 35.30 & - \\
\hline
\end{tabular}

$* \mathrm{CV}$ : Coefficient of variation; $* * \mathrm{R}^{2}$ : coefficient of determination.

It is important to emphasize that despite the high values of total dry matter availability (11-14 tons), it was unaffected by the changes in nitrogen levels, but had efficiency losses of $57 \%, 74 \%$, and $88 \%$ at levels of 100,200 , and $400 \mathrm{~kg} \mathrm{ha}^{-1}$, respectively, compared with that of $50 \mathrm{~kg}$. The production of pasture expressed as $\mathrm{kg}$ of dry matter per $\mathrm{kg}$ of nitrogen used was $83,120,71$, and $34 \mathrm{~kg}$ for the levels of 50,100,200, and $400 \mathrm{~kg} \mathrm{ha}^{-1} \mathrm{~N}$, respectively. It has been shown that the agronomic efficiency of nitrogen in forage productivity is usually reduced with an increase in the nitrogen dose in pastures (MELLO et al., 2008). In turn, the efficiency with respect to dry mass of leaf blades, was reduced from 58 (50 kg dose) to $9.8 \mathrm{~kg}$ (400 kg dose) of dry mass of leaf per kg of nitrogen applied.

The stocking rate (Table 2) displayed a linear increase $(\mathrm{P}<0.05)$ with the dose of nitrogen, which rose from 3.7 to $6.6 \mathrm{UA} \mathrm{ha}^{-1}$ from 50 and $400 \mathrm{~kg} \mathrm{ha}^{-1}$ $\mathrm{N}$, respectively, which was explained by the greater mass of leaf blades at higher nitrogen levels and the simultaneous management to ensure a higher stocking rate.

As a result of the increased stocking rate and similar individual gains, the live weight (LV) gain per ha (Table 2) showed a linear increase $(\mathrm{P}<0.05)$ in response to nitrogen levels as this variable is a 
function of the average daily gain and the stocking rate of pasture. Gains obtained in the range 653-813 $\mathrm{kg} \mathrm{LV} \mathrm{ha}{ }^{-1}$ were observed for the levels of $50-400 \mathrm{~kg}$ $\mathrm{ha}^{-1}$, respectively. Despite sharp increases in animal productivity, it is common to experience decreases in the conversion efficiency into $\mathrm{kg}$ of live animal weight per $\mathrm{kg}$ of nitrogen applied. In this case, the efficiency was $13,6.7,3.6$, and $2.0 \mathrm{~kg}$ live weight per $\mathrm{kg}$ of nitrogen applied.

Difante et al. (2010) investigated the same species in rotational grazing conditions and reported lower gains, between 559 and $601 \mathrm{~kg} \mathrm{ha}^{-1}$ for grazing pasture heights of 50 and $25 \mathrm{~cm}$, respectively, but used $67.5 \mathrm{~kg} \mathrm{ha}^{-1} \mathrm{~N}$. The results observed in this study and other studies related to animal production on pasture reveal that the management of the species and the level of fertilization adopted are crucial for good performance, whether for individual gain or by area. In another study that also used Tanzania grass, but with heights between 20 and $80 \mathrm{~cm}$, Barbero et al. (2014) found similar gains in the average weight per day to this study (mean values of $1.06 \mathrm{~kg} \mathrm{day}^{-1}$ ) with variations in the range $0.95-1.27 \mathrm{~kg} \mathrm{day}^{-1}$; the study was also conducted in the summer period.

The CP content of the leaf blades (Table 3) was linearly increased $(\mathrm{P}<0.05)$ with an increase in nitrogen levels, possibly as a result of the greater activity of the nitrate reductase enzyme in the leaves, which increases the proportion of nonprotein nitrogen and, consequently, the content of CP (LAVRES JUNIOR; MONTEIRO, 2006). In the comparison of the 50 and $400 \mathrm{~kg} \mathrm{ha}^{-1} \mathrm{~N}$ levels, there was an average increase of $18.3 \mathrm{~g} \mathrm{~kg}^{-1}$ of $\mathrm{CP}$ in the leaf blade. The increase of this nutrient may be of great importance in animal performance, as variation in the $\mathrm{CP}$ content of the leaves leads to increases in the rate of the instantaneous intake of cattle, as demonstrated by Rego et al. (2006), who evaluated the main structural and qualitative characteristics that influence the feeding behavior of the animals in Tanzania grass pasture.
The levels of CP obtained were lower than those reported by França et al. (2007), who observed variations of $57.8-142.8 \mathrm{~g} \mathrm{~kg}^{-1}$ of CP, and by Sousa et al. (2010), who found CP levels of $130 \mathrm{~g} \mathrm{~kg}^{-1}$ in Tanzania grass using $300 \mathrm{~kg} \mathrm{~N} \mathrm{ha}^{-1}$.

The NDF content of the leaf (Table 3) showed a negative linear dependence on the levels of nitrogen, decreasing from 713.8 to $734.8 \mathrm{~g} \mathrm{~kg}^{-1}$. Using these data, we can infer that the higher frequency of grazing interferes with the quality of the plant; with higher loads used at higher levels of nitrogen, the leaves had a lower proportional cell wall content, because they are younger. The levels of NDF agreed with those reported by Euclides et al. (2007), who evaluated different grazing intensities. These values are highly relevant to animal nutrition as the neutral detergent fiber is the component of the forage more consistently associated with consumption: when the NDF levels of the plants rise from 70 to $80 \mathrm{~g} \mathrm{~kg}^{-1}$, a reduction in the consumption from 70 to $50 \mathrm{~g}$ per $\mathrm{kg}^{0.75-1}$ was observed (VAN SOEST, 1994).

The NDF content of the leaf blades (Table 3) displayed a negative linear behavior with nitrogen dose, decreasing from 794 to $770 \mathrm{~g} \mathrm{~kg}^{-1}$. The higher frequency of grazing at higher levels may have caused greater tillering through the stimulation of axillary buds, thus providing young tillers of tissues with higher cellular content, and consequently to a reduction in the levels of the components of the cell wall.

In agreement with the present data, Benett et al. (2008) found that nitrogen fertilization tends to improve the chemical composition of forage through an increase the levels of $\mathrm{CP}$ and a decrease in the levels of NDF, as observed in Brachiaria brizantha 'Marandu'. 
Table 3. Average values of crude protein content of the leaf blade (CPL, $\mathrm{g} \mathrm{kg}^{-1}$ ) and the stem (CPS, $\mathrm{g} \mathrm{kg}^{-1}$ ), neutral detergent fiber in the leaf blade (NDFL, $\mathrm{g} \mathrm{kg}^{-1}$ ) and the stem (NDFS, $\mathrm{g} \mathrm{kg}^{-1}$ ), and in vitro digestibility of leaf blade (IVDL, $\mathrm{g} \mathrm{kg}^{-1}$ ) and the stem (IVDS, $\mathrm{g} \mathrm{kg}^{-1}$ ) in Tanzania grass fertilized with different nitrogen rates.

\begin{tabular}{|c|c|c|c|c|c|c|c|}
\hline \multicolumn{5}{|c|}{ Nitrogen rates $\left(\mathrm{kg} \mathrm{ha}^{-1}\right)$} & \multirow[b]{2}{*}{ Equation } & \multirow[b]{2}{*}{${ }^{*} \mathrm{CV}(\%)$} & \multirow[b]{2}{*}{${ }^{* *} \mathrm{R}^{2}$} \\
\hline Variables $\left(\mathrm{g} \mathrm{kg}^{-1} \mathrm{DM}\right)$ & 50 & 100 & 200 & 400 & & & \\
\hline CPL & 91.8 & 93.1 & 103.6 & 110.1 & $\mathrm{Y}=88.0+0.5 \mathrm{X}$ & 21.50 & 0.8 \\
\hline CPS & 45.1 & 52.7 & 47.7 & 61.5 & 51.8 & 30.32 & - \\
\hline NDFL & 734.8 & 726.8 & 730.6 & 713.8 & $Y=751-0.2 X$ & 3.30 & 0.9 \\
\hline NDFS & 794.0 & 785.8 & 789.4 & 770.9 & $\mathrm{Y}=796-0.06 \mathrm{X}$ & 3.45 & 0.8 \\
\hline IVDL & 689.8 & 674.7 & 686.0 & 685.2 & 683.8 & 7.78 & - \\
\hline IVDS & 624.0 & 632.4 & 640.7 & 637.8 & $Y=616+0.2 X-0.0004 X^{2}$ & 3.82 & 0.9 \\
\hline
\end{tabular}

${ }^{*} \mathrm{CV}$ : Coefficient of variation; $* * \mathrm{R}^{2}$ : coefficient of determination.

The in vitro digestibility of the leaf blades (Table 3) did not display differences $(P>0.05)$ between the nitrogen levels, with mean values of $683 \mathrm{~g} \mathrm{~kg}^{-1}$, which allowed the animals to gain approximately $1 \mathrm{~kg} \mathrm{~d}^{-1}$. The digestibility of the stem (Table 3) displayed a quadratic tendency, with the maximum value at a level of $205.4 \mathrm{~kg} \mathrm{ha}^{-1}$, which indicated that higher levels of nitrogen negatively influenced the quality of the stems and reduced their digestibility. Other studies have demonstrated that changes in height management lead to marked changes in the quality of plant components. Rego et al. (2004) evaluated heights between 20 and 80 $\mathrm{cm}$ and reported decreases in leaf digestibility with increases in management height. Cano et al. (2004) investigated different pasture heights in Tanzania grass and reported levels in the range $640-670 \mathrm{~g} \mathrm{~kg}^{-1}$ DM for a height of $50 \mathrm{~cm}$ in evaluations conducted between November and March, respectively, with nitrogen fertilization of $250 \mathrm{~kg} \mathrm{ha}^{-1} \mathrm{~N}$ under grazing.

\section{Conclusions}

An increase in the nitrogen rates in the fertilizer used for Tanzania grass improved chemical composition and animal production. A nitrogen dose of $200 \mathrm{~kg} \mathrm{ha}^{-1}$ was indicated to result in the most improvements with respect to the variables studied.

\section{Acknowledgements}

We would like to thank Professor Wilson Mattos, rector of Unicesumar, for funding the research, and professor Dr. Luiz Paulo Rigolon, for hosting the survey on his property (Sitio Olho d'Água).

\section{References}

ASSOCIATION OF OFFICIAL ANALYTICAL CHEMISTS - AOAC. Official methods of analysis. 15. ed. Washington: AOAC, 1990.

BARBERO, R. P.; BARBOSA, M. A. A .F.; CASTRO, L. M.; RIBEIRO, E. L. A.; MIZUBUTI, I. Y.; BUMBIERIS JÚNIOR, V. H.; SILVA, L. D. F.; MASSARO JÚNIOR, F. L. Desempenho de novilhos de corte em pastos de capim-Tanzânia sob quatro alturas de desfolha. Arquivo Brasileiro de Medicina Veterinária e Zootecnia, Belo Horizonte, v. 66, n. 2, p. 481-488, 2014.

BENETT, C. G. S.; BUZETTI, S.; SILVA, K. S.; BERGAMASCHINE, A. F.; FABRICIO, J. A. Produtividade e composição bromatológica do capimMarandu submetido a fontes e doses de nitrogênio. Ciência e Agrotecnologia, Lavras, v. 32, n. 5, p. 16291636, 2008.

BRAGA, G. J.; LUZ, P. H. C.; HERLING, V. R.; LIMA, C. G. Resposta do capim-Mombaça a doses de nitrogênio e a intervalos de corte. Acta Scientiarum Animal Sciences, Maringá, v. 26, n. 1, p. 123-128, 2004.

CANO, C. C. P.; CECATO, U.; CANTO, M. W.; SANTOS, G. T.; GALBEIRO, S.; MARTINS, E. N.; MIRA, R. T. Valor nutritivo do capim-Tanzânia (Panicum maximum Jacq. cv. Tanzânia-1) Pastejado em Diferentes 
Alturas. Revista Brasileira de Zootecnia, Viçosa, v. 33, n. 6, p. 1959-1968, 2004.

CANTO, M. W.; JOBIM, C. C.; GASPARINO, E.; HOESCHL, A. R. Características do pasto e acúmulo de forragem em capim-tanzânia submetido a alturas e manejo do pasto. Pesquisa Agropecuária Brasileira, Campo Grande, v. 43, n. 3, p. 429-435, 2008.

DIFANTE, G. S.; EUCLIDES, V. P. B.; NASCIMENTO JÚNIOR, D.; SILVA, S. C.; BARBOSA, R. A.; TORRES JUNIOR, R. A. A. Desempenho e conversão alimentar de novilhos de corte em capim-tânzania submetido a duas intensidades de pastejo sob lotação rotativa. Revista Brasileira de Zootecnia, Viçosa, v. 39, n. 1, p. 33-41, 2010.

EMPRESA BRASILEIRA DE PESQUISA AGROPECUÁRIA - EMBRAPA. Centro Nacional de Pesquisa de Solos. Sistema Brasileiro de Classificação de Solos. Rio de Janeiro, 2013.

EUCLIDES, V. P. B.; COSTA, F. P.; MACEDO, M. C. M.; FLORES, R.; OLIVEIRA, M. P. de. Eficiência biológica e econômica de pasto de capim-tanzânia adubado com nitrogênio no final do verão. Pesquisa Agropecuária Brasileira, Campo Grande, v. 42, n. 9, p. 1345-1355, 2007.

EUCLIDES, V. P. B.; MACEDO, M. C. M.; ZIMMER, A. H.; JANK, L.; OLIVEIRA, M. P. de. Avaliação dos capins Mombaça e Massai sob pastejo. Revista Brasileira de Zootecnia, Viçosa, v. 37, n. 1, p. 18-26, 2008.

FRANÇA, A. F. S.; BORJAS, A. L. R.; OLIVEIRA, E. R. O.; SOARES, T. V.; MIYAGI, E. S.; SOUSA, V. R. Parâmetros nutricionais do capim-Tanzânia sob doses crescentes de nitrogênio em diferentes idades de corte. Ciência Animal Brasileira, Goiânia, v. 8, n. 4, p. 695703, 2007.

GARDNER, A. L. Técnicas de pesquisa em pastagens e aplicabilidade de resultados em sistemas de produção. Brasília, DF: Embrapa-CNPGL, 1986. 197 p.

LAVRES JUNIOR, J.; MONTEIRO, F. A. Diagnose nutricional de nitrogênio no capim-aruana em condições controladas. Revista Brasileira Ciência do Solo, Viçosa, v. 30, n. 5, p. 829-837, 2006.

MAGALHÃES, A. F.; PIRES; A. J. V.; CARVALHO, G. G. P.; SILVA, F. F.; SOUSA, R. S.; VELOSO, C. M. Influência do nitrogênio e do fósforo na produção do capim-Braquiária. Revista Brasileira de Zootecnia, Viçosa, v. 36, n. 5, p. 1240-1246, 2007.

MARTHA JUNIOR, G. B.; CORSI, M.; BARIONI, L. G.; VILELA, L. Intensidade de desfolha e produção de forragem do capim-tanzânia irrigado na primavera e no verão. Pesquisa Agropecuária Brasileira, Brasília, v. 39, n. 9, p. 927-936, 2004.

MELLO, S. Q. S.; FRANÇA, A. F. de S.; LANNA, A. C.; BERGAMASCHINE, A. F.; KLIMANN, H. J.; RIOS, L. C.; SOARES, T. V. Adubação nitrogenada em capim-mombaça: produção, efi ciência de conversão e recuperação aparente do nitrogênio. Ciência Animal Brasileira, Goiânia, v. 9, n. 4, p. 935-947, 2008.

MINSON, D. J. Forage in ruminant nutrition. San Diego: Academic Press, 1990. 483 p.

MOTT, G. O.; LUCAS, H. L. The desing, conduct, and interpretation of grazing trials on cultivated and improved pastures. In: INTERNATIONAL GRASSLAND CONGRESS, 6., 1952, Pennsylvania. Proceedings... Pennsylvania: State College Press, 1952. p. 1380-1385.

PARIZ, C. M.; ANDREOTTI, M.; BERGAMASCHINE, A. F.; BUZETTI, S.; COSTA, N. R.; CAVALLINI, M. C.; ULIAN, N. A.; LUIGGI, F. G. Yield, chemical composition and chlorophyll relative content of Tanzania and Mombaça grasses irrigated and fertilized with nitrogen after corn intercropping Revista Brasileira de Zootecnia, Viçosa, v. 40, n. 4, p. 728-738, 2011.

PETERSEN, R. G.; LUCAS, H. L. Computing method for the evalution of pasture by means of animal response. Agronomy Journal, Madison, v. 60, n. 6, p. 682-687, 1968.

REGO, F. C. A.; DAMASCENO, J. C.; MARTINS, E. N.; CORTES, C.; FUKUMOTO, N. M.; ROESHI, L.; SANTOS, G. T. Influência de variáveis químicas e estruturais do dossel sobre a taxa de ingestão instantânea em bovinos manejados em pastagens tropicais. Revista Brasileira de Zootecnia, Viçosa, v .35, n. 3 p. 691-698, 2006.

REGO, F. C. A.; CECATO, U.; DAMASCENO, J. C.; RIBAS, N. P.; SANTOS, G. T.; MOREIRA, F. B.; RODRIGUES, A. M. Valor Nutritivo do Capim-Tanzânia (Panicum maximum Jacq cv. Tanzânia-1) Manejado em Alturas de Pastejo. Acta Scientiarum Animal Sciences, Maringá, v. 25, n. 2, p. 363-370, 2004.

RIBEIRO, O. S.; CECATO, U.; IWAMOTO, B. S.; PINHEIRO, A.; JOBIM, C. C.; DAMASCENO, J. C. Desempenho de bovinos em capim-tânzania adubado com nitrogênio ou consorciado com Estilosantes. Revista Brasileira de Saúde e Produção Animal, Salvador, v. 12, n. 1, p. 275-285, 2011.

STATISTICAL ANALYSIS SYSTEM INSTITUTE SAS. Statistics analysis systems: user guide. Washington, DC, 1999. 842 p. 
SOARES FILHO, C.V.; CECATO, U.; RIBEIRO, O. L.; ROMA, C. F. C.; BELONI, T. Morphogenesis in pastures with Tanzania grass fertilized with nitrogen doses under a grazing system. Acta Scientiarum: Animal Sciences, Maringá, v. 37, n. 3, p. 235-241, 2015.

SOUSA, R. S.; PIRES, A. J. V.; CARVALHO, G. G. P.; SILVA, F. F.; MAGALHÃES, A. F.; VELOSO, C. M. Composição química de capim-tanzânia adubado com nitrogênio e fósforo. Revista Brasileira de Zootecnia, Viçosa, v. 39, n. 6, p. 1200-1205, 2010.
TILLEY, J. M. A.; TERRY, R. A. A two stage technique for the in vitro digestion of forage crops. Grass and Forage Science, Kenilworth, v. 18, n. 2, p. 104-111, 1963.

VAN SOEST, P. J. Nutritional ecology of the ruminant. 2. ed. New York, NY: Cornell University, 1994. 475 p.

VAN SOEST, P. J.; ROBERTSON, J. B.; LEWIS, B. A. Symposium: carbohydrate methodology, metabolism, and nutritional implications in dairy cattle. Journal of Dairy Science, Champaign, v. 74, n. 10, p. 3583-3597, 1991. 
